\title{
1. Révolution, Rechtsstaat and the Rule of Law: historical reflections on the emergence and development of administrative law Bernardo Sordi
}

The historical origins and evolution of administrative law continues to be a controversial issue. While some scholars identify a strong continuity between pre-modern and contemporary reality (Mestre 1985; Craig 2015), other interpretations emphasize a fundamental rift in the eighteenth century: with the displacement of the Ancien Régime by the French Revolution, jurists for the first time defined a conception of 'administrative law,' distinguishing administrative bodies, functions and duties from those of the judiciary (Mannori-Sordi, 2001; 2009).

This chapter pursues the second interpretation. Without denying certain hidden continuities, it explores the discontinuity of language, terminology, and concepts that was most clearly marked between the end of the eighteenth century and the start of the nineteenth. It is worth noting that the terms administration publique and bureaucratie make their appearance in France around the mid-eighteenth century; the term droit administratif is confirmed only in the first years of the nineteenth century. With the end of the eighteenth century, a complex comparative legal history began. The terminologies and the contents of the 'administrative' legal universe were not identical across jurisdictions, nor did the different national experiences take place with the same chronology.

The descriptive terms Rechtsstaat, Etat de droit, and Rule of Law were coined in legalpolitical thought to describe the new structures of public power. These concepts are not immediately equivalent to each other, and for a long time they maintained important traits of individuality. This chapter aims to briefly reconstruct their development, presuming that the emergence of the administrative power and of a law defined as administrative is an intrinsically modern problem, that cannot be dated back to before the end of the eighteenth century. It traces the broad contours of the administrative law of France, Germany, England, and, later, the United States through the mid-twentieth century.

\section{RÉVOLUTION: THE FRACTURE LINE AT THE ORIGIN OF ADMINISTRATIVE MODERNITY IN EUROPE}

At least since the publication of Tocqueville's 1856 masterpiece, L'Ancien Régime et la Révolution, scholars have raised questions about the continuity or discontinuity across the divide marked by 1789. In one of his most famous passages, Tocqueville himself asked whether Richelieu would have been pleased with 'the new order of things' emerging in the first year of the Revolution (Tocqueville 1969: 96). To what extent did the administrative inheritance of the ancien régime continue to condition institutional and legal decisions throughout the Revolutionary decade and after? At what point do state functions become 
broadly perceived as 'administrative', separated from other forms of public power, like defence and public order?

To mark the emergence of administrative power as such, we have nothing comparable to the seemingly precise dates in history (for example, during the American or French Revolutions) when a 'constituent' power - the 'nation', or the 'people' - purported to abrogate a constitution ancienne, proclaiming the principle of legal equality in place of centuries-old hierarchies and corporatist distinctions. We also have nothing comparable to the adoption of a new code civil that, in much of continental Europe at least, created a new legal order able to unify the old legal pluralism.

The emergence of administrative power, which was closely followed by that of administrative law, unfolded over a longer time span, which undoubtedly included the Revolutionary decade and a good portion of the Napoleonic era. However, administrative power could not separate itself so sharply from its roots under the ancien régime. Indeed, at the end of the seventeenth century, an ancien régime jurist like Jean Domat could classify public powers in a triad of justice, police, finance (Domat 1756: II, I, I, 15 , p. 151), symbolizing the growing complexity of the absolute monarchy and the first significant imposition of sovereignty over corporatist society. Administrative power and law, therefore, undoubtedly have an ancient soul, deeply bound up with the capacity of political absolutism to govern.

And yet, in the legal universe of the ancien régime, the power of command generally remained firmly in the hands of ordinary judicial jurisdictions. Governance in old Europe was very much juridictionnel - that is, tied to the vast array of adjudicative bodies - even as the bureaucratic apparatus of the emergent absolute monarchies expanded. This situation eventually gave rise to a political and legal dialectic between justice and what would, by the mid-1700s, come to be defined as administration publique. New forms of gouvernamentalité (Foucault 1994) or arts de gouverner (Senellart 1995) emerged in the eighteenth century, marked by an intense and completely new regulatory attention to the population and the territory as a whole.

The Revolution of 1789 therefore did not so much invent but rather catalyze administration publique. It reformulated institutional and conceptual materials that had been developing since at least the middle of the seventeenth century. But in breaking definitively and abruptly with the old corporatist order, the French Revolution also marked a critically important fracture line. The Revolution radically overturned the organization, functions, and conceptual-legal vocabulary of the old regime.

'The gigantic broom of the French Revolution', as Marx called it (1973: 218), also operated with great intensity on the terrain of administration, marking an irreversible point of no return. Innovations in social and political organization - most importantly the abolition of corporate bodies and the creation of a single class of citizens - loom large in our analysis: As Tocqueville put it, 'equality facilitates the exercise of power' (1969: 98). In the place of the old corporate order, an enormous empty space emerged between the state and the individual citizen, artificially conceived as isolated. The Assemblée Constituant replaced the old institutional patchwork of gothic overlaps with an ordered, thorough, and hierarchical pyramid of districts and apparatuses, seemingly geometrical in their dimension, organization and function. The old société de sociétés (Portalis 1999: 14) disappeared for good. The state conquered the centre of power once and for all, and became the exclusive artificer of the legal and institutional order. 
The composite monarchy of the past, with its heavy reliance on corporatist adjudication, would make way for a machine-state with its own institutional capacities, pursuing its own tasks and its own interests. Political obligation became simpler: henceforth, the institutional map encompassed only two figures, that of the state, on one hand, and that of the citizen, on the other, which occupied and shared the political space.

It is at this point that one sees the birth of 'administration' in a modern sense. The separation of powers was proclaimed generically in article 16 of the Declaration of Rights of Man, and was first articulated functionally and organizationally in the decree concerning the institution of primary assemblies and administrative assemblies of December 22,1789 . The institutionalization of the separation of powers continued throughout the Revolutionary and Imperial periods, with the law of August 16-24, 1790 prohibiting ordinary judicial courts from reviewing administrative acts, the first regulations attributing jurisdiction of the affaires contentieuses to the administration and, lastly, the law of 28 Pluviôse, Year VIII (February 17, 1800) concerning the division of French territory and the administration. Each of these acts helped to shape the specificity and subjectivity of administration as a separate and distinct form of public power.

Parallel to this new manner of exercising sovereign power, which the Revolution defined as administrative, a new manner of describing and conceptualizing public power took hold, radically different from the old notions. The French Revolution went beyond a simple constitutional acknowledgement of the public rights of an administrative power that had existed since the formation of the modern state. This traditional nineteenthcentury reading of the transformation of the Polizeistaat into the Rechtsstaat (something we take up in the next section) did not fully grasp how the exercise of sovereignty led to the suppression of corporate society and did not adequately capture the monopolistic concentration of public tasks into the hands of the state. 'Administrative power' and 'administrative law' emerged contemporaneously. The shift from corporatist society to liberal society required a machine state with the 'rapidité du fluide électrique' (Chaptal 1800). It also required the invention of new institutional and legal guarantees - first and foremost, administrative justice. Finally, it entailed a new dialectic between centre and periphery, seeking legal uniformity and control, while also allowing for decentralized spaces.

However one chooses to interpret the link between the ancien régime inheritance and the revolutionary innovations, the new juridical discipline of administrative law makes its first appearance on the continent in the strategic passage out of the late eighteenth century. It then fully unfolds in the nineteenth century, which throughout Europe becomes 'the century of administration (Verwaltung) and of the emergence of administrative law (Verwaltungsrecht)' (Stolleis 1992: 229).

But it was France, during the Napoleonic era, that marked the definitive emergence of droit administratif, with the birth of the contentieux administratif and the new regime of administrative acts. Justice and administration were firmly divided and separated: juger l'administration c'est encore administrer ('to judge the administration is still to administer'). For the ordinary courts, judicial review of the administrative action was impossible: the ordinary judge could only adjudicate civil and criminal cases. A centralized administration, endowed with its own adjudicative capacities, guided and controlled a country that Tocqueville described as an equal surface. Modernity henceforth had the unmistakable seal of administration. 
In the classical declination of the separation of powers by Montesquieu, distinguishing between 'the executive with respect to things dependent on the law of nations' (peace, war, diplomacy) and 'the executive in regard to matters that depend on the civil law', or rather civil and penal jurisdiction (Montesquieu 1914: XI, 6), a subject of a new type interposed itself between 'the general order of the state' and jurisdiction, labelled for the first time as administration générale de l'État. This new subject assumed the multitude of regulatory tasks that the prince and the corporate bodies of the ancien régime had previously divided between them. Administrative power and law now appeared on the continent as irreplaceable pilasters of the entire liberal society: 'une des formes de l'État nouveau du monde; nous l'appelons le système français; c'est le système moderne qu'il faut dire' (Tocqueville 1866: 73).

\section{RECHTSSTAAT: THE GERMAN CONCEPTUAL CONTRIBUTION AND THE LEGAL LIMITS OF ADMINISTRATIVE POWER}

Even in countries like Prussia and Austria, which were seemingly immune from the French revolutionary events, there were pressures toward the development of administration and administrative law. Rather than abrupt revolutionary shifts, however, Prussia and Austria witnessed the slow advance of reforms. As in France, these reforms began in the mideighteenth century and gathered momentum in the context of the Napoleonic wars. But unlike France, there were no clear constitutional ruptures, no overthrow of the existing corporate order. On the level of legal language, the transformation was also less pronounced: for decades, the new language of administrative law continued to coexist with older conceptual terms and traditions, first and foremost the eighteenth-century notion of Polizeiwissenschaft (Police Science).

Once the idea of administration as a power of the state over society gained widespread acceptance, the European continent witnessed a profound reconsideration of the nature of political obligation, which became centred on the state-citizen relationship and the authority-freedom dialectic. A new theme emerged, that of legal guarantees for society and for the individual. The end of the Revolution indeed left a formidable administrative machine on the institutional landscape, endowed with a vast and unprecedented number of imperative powers to dispose of the properties and freedom of private parties. Administration emerged as a strategic support of an atomized and dispersed society suddenly deprived of its centuries-old corporative ties. But, at the same time it emerged as a pressing danger for individual rights. Nineteenth-century administration served as both a condition for, and a menace to, the freedom of the moderns. It became necessary to define legal limits and guarantees within the confines of a system of administrative 'justice' worthy of the name and to develop means whereby liberal society could defend itself against the absolutely unprecedented concentration of public powers. Political freedom certainly did not exclude administrative despotism. On the contrary, as Tocqueville observed in Démocratie en Amérique (with a pinch of regret for the pluralist order displaced by the Révolution), it is precisely 'those democratic peoples which have introduced freedom in the sphere of politics' who also increased 'despotism in the administrative sphere' (Tocqueville 1994: 694). 
Much of nineteenth-century legal development, at least in the realm of administration, focused on checking powers, functions and offices. Drastic amputations of responsibilities and functions were felt necessary; new balances between centre and periphery were understood to be needed to temper the unbearable administrative centralism; and substantial restitutions to the social sphere were urged, mostly in vain, in order to escape the providential crutches of the state. Calls for decentralization were recurrent in liberal European society from the 1830s onward. There was a palpable desire to re-establish relationships between society, territory, and public power that were less artificial and mechanical than in the Napoleonic era, and therefore more solid and profound. Concerns were less about the lack of democratic control than about the administration's seeming separateness from society, most importantly from the influence of local notables. Adding to the atmosphere of liberal anxiety was the rise of the 'social question' - the increasing tensions between the working classes and the bourgeoisie in a period of industrialization and urbanization - which made itself felt both in the revolutions of 1848, and then later in the Paris Commune of 1871, posing a challenge to the precarious liberal hegemony.

The inexorable development of administrative power captured the attention of jurists and politicians. Old representations of power were set aside; new typological models emerged. Most importantly, continental jurists developed the idea of the Rechtsstaat (Stolleis 1982), a new theoretical lemma which originated in German doctrine but rapidly found equivalent expressions in other continental European legal languages (Stato di diritto, État de droit, Estado de derecho). This typological model sought to reconcile the new 'laws of freedom' (Kant 1991: 129) with the eclipse of the judicial regimes of the old order and the full deployment of state sovereignty through administrative power that emerged in the Revolutionary and Napoleonic eras. In German legal culture, from Kant to Mohl, from Stahl to Gerber, from Hegel to Stein, from Bähr to Gneist (Stolleis 1992) - indeed, in continental legal culture as a whole - the Rechtsstaat expressed both the new demand for guarantees as well as the acknowledgment of the irrevocable transformations since the end of the eighteenth century. The goal was to circumscribe the enormous power that executive administrations had conquered with the French Revolution and the Napoleonic era.

The notion of Rechtsstaat sought to reconcile the 'freedom of the state' with that of the citizen; it attempted to make the primacy of the administration compatible with the respect for individual guarantees. It reflected the broadly accepted idea that power and freedom developed symbiotically. The Rechtsstaat was thus never conceptualized as a spontaneous, natural order, pre-existent to power. On the contrary, rights would cohabit with a sovereignty personified by the centrality of legislation, which became the principal guarantee of rights. Hence the increasing importance of the principle of legality in Verwaltungsrecht: from this moment onward, the prerequisite for every manifestation of authority was the legal source.

It was therefore the task of nineteenth-century legal doctrine to conceptualize administration both as a power and as a field needing legal limits. Administrative legality came to be understood as an essential guarantee of freedom. As numerous commentators reiterated in different national contexts over the course of the nineteenth century, from Barthold Georg Niebuhr to Rudolf von Gneist to Silvio Spaventa, up to the American Woodrow Wilson: 'liberty depends incomparably more upon administration than upon 
constitution' (Wilson 1887: 211). This was a significant affirmation. On one hand, it pointed to the fact that, in Europe at least, constitutional review of legislation was still a distant goal. On the other hand, it suggested that it was in the administrative context, where the construction of power was strongest and most incisive, that the provision of efficient guarantees of rights was perceived as the most urgent task. Legal control of administrative action became the banner of the century: in the administrative universe, power and freedom did indeed advance hand in hand.

It was precisely in this search for a kind of judicial review of administrative action that the ideal of the Rechtsstaat acted as a force for institutional modernization. Administrative justice stood as a guarantee of legality, as a mechanism to ensure the administration's conformity to the law. But because administrative action was immune from the control of the ordinary courts, administrative justice would not, strictly speaking, entail 'judicial review'. Rather, the continental interpretation of the separation of powers required the establishment of a new, specifically 'administrative' judge, one who was often organically attached to the executive (as with the French Conseil d'Etat), or at least separate from the ordinary courts.

In short, we can say that the continental model of the Rechtsstaat entailed three fundamental elements: the supremacy of the legislative power, the existence of a strong administrative power, and the existence of a special judge for administrative matters.

\section{RULE OF LAW: THE ANGLO-AMERICAN VARIANT IN THE LAW OF ADMINISTRATION}

At first glance, the English path diverged sharply from the continental route, whether measured by the abrupt changes engendered by the French Revolution, or the slow progression of reforms in the Austrian-German context. Instead, the English process of constitutional modernization was much older, the process of displacing corporative pluralism in favour of a more individualist order was slower and arguably less painful, and the primacy of Parliament was more deeply rooted and undisputed. The construction of a modern public authority thus proceeded in parallel rather than in conflict with the expansion of political participation, which conserved and transformed, but did not deny, the old pluralism of freedoms. Thus, the pre-eminent vocation of the state could still be that of mediating between divergent interests rather than that of expressing unitary values. 'Justice' associated with the common law courts, rather than absolutist 'administration', remained central.

English administrative development can be traced to distinctive features of its law and culture: 'the importance given to institutional continuity within the common law habit of thinking' was essential to the 'Whig fundamentalism' that was by far the prevailing interpretation of English constitutionalism, expressing the 'high degree of cohesion within the governing class' (Loughlin 2009: 156, 163). As a consequence, England did not exhibit the same fracture lines that were taking shape in continental history. The peculiarities of the English state, on one hand, combined with a very resistant way of thinking, on the other, represented an insurmountable barrier to the development of an administrative apparatus on the continental model. The old and traditional judicial model for the exercise of public power did not lend itself to radical transformation; moreover, there was 
no similar lexical revolution in England as occurred on the continent with the end of the eighteenth century.

And yet, in England too, the nineteenth century saw an administrative space progressively take root, prompted by the demands and problems that exploded with the Industrial Revolution. This space emerged gradually, in a perhaps confused and disorderly manner, in response to specific and concrete problems posed by a rapid urbanization, the emergence of the social question, and the need to regulate the socio-economic relations that broke sharply with the past (reflected on the constitutional level in the increasingly more insistent pressures to extend suffrage). Case by case, through a process of learning by experience, an administrative apparatus developed, which focused variously on the regulation of work, railways, health, public education, and poor relief. Thus, in England too, 'administration' - even if not understood in a continental sense - began to flank the traditional judicial apparatus. 'The great body of such changes were natural answers to concrete day-to-day problems, pressed eventually to the surface by the sheer exigencies of the case' (MacDonagh 1958: 65). Built either by statute or by the shift of regulatory authority to the executive ('delegated legislation'), England saw the creation of a broader network of administrative authorities holding executive prerogatives and discretionary powers.

The appearance of a functionally driven and unplanned administrative centralization, with the institution of the first boards and central departments, as well as the birth of administrative forms of adjudication beyond the purview of the common law courts, increasingly displaced Parliament as the hinge between central and local government, and complicated the traditional judicial model of the exercise of public power. Nevertheless, these developments did not impose an epochal change in the state organization or the adoption of new legal categories comparable to the French administration publique or to the Staatsgewalt of the German tradition. Instead, they were generally regarded as exceptional, inserted among the consolidated principles of common law governance. Even local government in England, though heavily influenced since the early Victorian age by the profound functional transformations affecting both state and society more generally, conserved features of strong continuity with the previous territorial constitution. England gradually grafted administrative innovations onto the fabric of common law, updating but not altering the furrow of tradition and the relative conceptual universe.

Most importantly, England did not establish a specifically 'administrative' judge whose constitutional function would be to defend administrative prerogatives. It was thus unnecessary to alter the traditional way of thinking, which regarded the common law courts as the pre-eminent defenders of the 'Rule of Law', to which all litigants, including the executive, had to submit. Indeed, in nineteenth-century England, the very idea of the Rule of Law emerged in legal scholarship explicitly to delimit administrative powers analogous to those of the continent. In this, the idea of the Rule of Law shared much with the Rechtsstaat: both sought to reconcile state sovereignty with the need for legal guarantees of individual rights, and both acknowledged a general presumption of freedom, as well as the primacy of individual property. Indeed, both the Rechtsstaat and the Rule of Law acknowledged the pre-eminence of legislation: in the first case, as the expression of the sovereignty of the state, and in the second as the expression of 'Parliamentary Sovereignty' - 'the sovereign and uncontrollable authority' of Parliament, as Blackstone had long before put it (Blackstone 1884: 159). Finally, both reflected considerable prudence towards what appeared to be a dangerous democratic drift, certainly in terms of 
the generalization of political rights, but also in terms of social rights, the development of which remained far in the future.

Strong divergences remained, however. The continental concept of Rechtsstaat referred to a state that stood above society, instituting and rationalizing the social sphere, privileging legislative over customary law, entrusting absolute centrality to codification. The Rechtsstaat was also a markedly administrative state, as we have seen, manifesting this axiom in continental legal science: 'one can conceive of a despot who governs without laws and without judges, but a State without an administration would be anarchy' (Jellinek 1914: 612; and see the bitter objections of Kelsen 1968a: 2, 1647). On the continent, the centrality of administration translated into the idea that the administrative sphere expressed the very essence and continuity of the state's sovereignty. It did so on the level of organization, by means of centralized administrative control of the periphery. It did so on the level of law, through the regime of the acte administratif and justice administrative, which prevailed in the face of contrary claims of common law and judicial authority exercised by the ordinary courts.

The Rule of Law in England, by contrast, confirmed itself as a purely and typically judicial regime in which there had to be a compromise between the omnipotence of Parliament, though formally acknowledged, and the substantial intangibility of the 'common law of the land', in which the execution of the law and respect for common law rights was still essentially the duty of the jurisdictional function. As a consequence, an administrative sphere distinct from the legislative and the judicial powers, one capable of affecting the rights of citizens, encountered a number of legal-conceptual obstacles in its struggle to emerge. It was no coincidence that only in the English milieu did the common law courts succeed in monopolizing (at least well into the twentieth century) the forms of judicial defence before public power, preserving the unity of jurisdiction. On the organizational level, the greater weight of local government, with its separate functionaries, duties, and financial autonomy, along with a persistent non-bureaucratic ideal of self-government, drastically marked the limits of the dimensions and activity of the central administration and delayed the bureaucratization of the civil service. This explains why, from John Stuart Mill to Walter Bagehot, nineteenth-century commentators classified the English system as a non-bureaucratic order, viewing bureaucracy as a typically continental creature.

Even in the late nineteenth century, when the gap between the continental administrative regime and the persistent English judicial regime closed considerably, Dicey 'emphasized, not the state, but the "ordinary law" applied by the "ordinary law courts" as the cornerstone of the English system (Allison 1996: 72). Dicey expressly based his understanding of the English constitution on what he discerned as the three founding principles of the Rule of Law: first, 'the absolute supremacy or predominance of regular law as opposed to the influence of arbitrary power', which excludes 'the existence of arbitrariness, of prerogative, or even of wide discretionary authority on the part of the government'; second, the 'universal subjection of all classes to one law administered by the ordinary courts'; and finally, the preservation of 'the rights of individuals' via the negation of any droit administratif in England (Dicey 1959: part 2, chapters 4 and 12). The historian F.W. Maitland was considerably more cognizant than Dicey of the increasingly administrative character of Victorian governance (Maitland 1908: 505); nevertheless, he too reaffirmed the English divergence from the path of the Rechtsstaat, which consisted primarily in the absence of bureaucratization comparable to that on the continent. According to Maitland, in 
England 'we have no practical experience of a Polizeistaat or Beamtenstaat' (1987: XLIII). Continental jurists, by contrast, unvaryingly conjugated the Rechtsstaat with the existence of a system of separate administrative judges, now recognized as the cornerstone of the administrative regime. In the most famous handbook of administrative law of Wilhelmine Germany, Otto Mayer could thus identify the Rechtsstaat precisely with the state having 'a well-ordered administrative law' (Mayer 1924: vol. 1, 58).

Even in England, however, by the end of the nineteenth century, the progress toward an 'administrative law' worthy of the name was a reality that observers found increasingly hard to ignore as a consequence of intense functional pressures on the state. As Woodrow Wilson put it in 1887, in terms that applied equally well to the English case: 'the functions of government are becoming every day more complex and difficult; they are also vastly multiplying in number' (Wilson 1887: 200). England, like its common law confrère across the Atlantic, was quickly filling the 'hole' in the constitution where administration might have been (Mashaw 2012: 30), as a consequence of nearly a century of institutional and regulatory experimentalism. Like Wilson, Maitland also saw that 'year by year the subordinate government of England was becoming more and more important' (Maitland 1908: 501). Dicey himself, in 1915, with an essay of unequivocal title, The Development of Administrative Law, acknowledged the emergence of a distinct legal regime (Dicey 1915).

\section{RECHTSSTAAT AND THE RULE OF LAW FACED WITH STATE INTERVENTIONISM}

At the beginning of the twentieth century, the previously distinct and different traditions of Rechtsstaat and the Rule of Law seemed to finally converge onto common and shared paths.

Frank Goodnow, an American legal scholar who had studied administrative law in Berlin with Rudolf von Gneist, diagnosed this development. In Comparative Administrative Law (1893), he described a common juridical world based on the universality of administrative law. His opinion represents an absolutely opposite point of view to that of Dicey: 'the general failure in England and the United States to recognize an administrative law is really due, not to the non-existence in these countries of this branch of the law but rather to the well-known failure of English law writers to classify the law' (Goodnow 1893: 6-7).

But had administrative law already managed to secure an unquestionably global dimension, reuniting legal language and institutions, previously marked by an unmistakeably national character? If the position expressed by Dicey in 1885 and his peremptory denial of the existence in England of administrative law was largely based on an erroneous representation of the reality of the situation in England, Goodnow's position was no less so.

In the pages of Comparative Administrative Law we witness a mechanical transplant of the German nineteenth-century theory of law and state into the common law world. Concepts, notions and definitions were imported directly from Germany and France. This is particularly evident with reference to three basic conceptual topics, alien to the Anglo-American mentality: the idea that administration represents the very essence of the state; the sharp distinction (a real conceptual divide) between public and private law and between administrative powers and judicial powers; and finally, the inherent public law nature of administrative law. 
Dicey's negationist interpretation was as false as Goodnow's idea of a natural convergence towards administrative law in continental Europe and the Anglo-American countries. On one hand, the noble lie of the Rule of Law; on the other hand, the noble lie of the universality of the German Rechtsstaat, in its typical declination based on the primacy of public administration. In other words, the idea that the Rule of Law would not permit the existence of a droit administratif was undoubtedly an ideological one, but so was the theory of convergence toward a common administrative system under the German theory of law and state.

Only in interwar Western Europe did a real convergence emerge between the two different mentalities. Faced with state interventionism and the development of the welfare state, legal scholars were finally pushed and encouraged to update their traditional juridical way of thinking.

The Weimar Constitution of 1919 epitomizes this shift of mentality. Social rights and 'life of the economy' became part of the constitutional framework. Social and economic democracy complicated the catalogue of civil rights. Public interest invested private law with a growing focus on production and economic organization. New juridical sectors acquired a new disciplinary autonomy such as the public law of economy, taxation law and labour law.

However, the problem was not exclusively German. On the contrary, the same shift from the liberal state to the welfare state was seen throughout Europe after World War I. The state's entrance into the economy was a generalized phenomenon in the Western world, caused by the influence of the war economy, the technological revolution, the impact of social conflict rekindled by the Russian Revolution, and by the financial instability that would explode with the world crisis of 1929. The liberal strategy of devolving the regulation of the economy to society was replaced by the state-regulated economy.

In the French Third Republic, Maurice Hauriou and Léon Duguit pointed out the great transformations of sovereignty already underway in the last decade of the nineteenth century. Before the First World War, in French juridical culture, la puissance publique 'the administration as the representative of the sovereign' in Goodnow's words (Goodnow 1893: 11) - was already flanked by another form of public activity, the principal function of which became that of 'giving satisfaction to the mass of elementary needs' (Duguit 1913: XVII). The French École du service public was the first to describe the unprecedented level of social and co-operative activity and the new dimension of service provision. Duguit in particular, according to the sociological inquiry of Emile Durkheim, developed a frame of general theory capable of depicting the strong growth of public tasks.

Hans Kelsen, the founder of the School of Vienna and one of the founding fathers of the Austrian Constitution in 1920, starting from a different theoretical basis, discovered the state of direct administration and distributive justice: 'the state that goes into action' (Kelsen 1968b). In German legal culture, Ernst Forsthoff and Ernst Rudolf Huber, two young legal scholars educated in the school of Carl Schmitt, developed a public law of the state economy and an administrative law of the public services during the 30 s, between the Weimar Republic and the Nazi regime. For these two thinkers, attention to the relevant modernizations which began in the performance of public functions with the First World War led to totalitarian tendencies.

The period of economic interventionism transverses the various political regimes. England, too, is marked by the spirit of the time. The End of Laissez Faire was published 
by John Maynard Keynes in 1926. Only one year before, in A Grammar of Politics, Harold Laski - a follower of Duguit's thought and the translator into English of his masterpiece, Law in the Modern State - defined the state as a 'public service corporation' whose activity unfolds toward the realization of a new economic and social democracy (Laski 1925).

Already in October 1927, in the introduction to the first edition of Justice and Administrative Law, William Robson was able to conclude on the basis of a specific juridical approach in the following way:

There can be no doubt that the rise of Administrative Law is mainly due to the vast extension in the work of government which has taken place in England during the past few decades, and to the rapid increase in power of the executive which has accompanied that extension. The traditional Court system, in which isolated individuals contest disputed rights of property or person, has been superseded by an entirely new type of judicial process so far as concerns controversies arising in connection with the new social services undertaken by the State (Robson 1928: XXX).

The different traditions of Rechtsstaat and Rule of Law thus started to converge in Europe for the first time; and they converged toward the depiction of a new social service state. From the continental legal scholars to the interdisciplinary English group at the London School of Economics (from Beveridge to Laski, from Robson to Jennings), administrative law marked out new boundaries between authority and individual rights, 'furthering a policy of social improvement' (Robson 1928: 438). The way to comparison was finally opened, notwithstanding 'the lurid journalism' (Frankfurter 1930: 157) of Lord Hewart and his infamous 1929 diatribe, The New Despotism (Lindseth 2005). Despite the persistent Dicey-based rhetoric therefore, even in England 'the State either through the central government or the local authorities, has "gone into business"' (Robson 1928: 443).

In the United States during the same years, the functions of the government were growing, driven by the needs of the second industrial revolution and the social question. A modern regulatory state was developing, able to accommodate the demands of modern society upon government and the growing 'interplay of economic enterprise and government' (Frankfurter 1930: 1-2). Thus, even in America 'those simple days' (Frankfurter 1930: 19) of limited government seemed far off now, symptoms of a nineteenth-century world: a world far away, marked by elementary needs and limited public functions.

Anticipated by the late nineteenth century creation of administrative agencies, Roosevelt's New Deal, with its political target of 'Freedom from Want,' seemed to follow a path in some respects similar to that of the European countries. The 'administrative oversight' of 'public utilities' and 'interstate public services' (Frankfurter 1930: 83-5) grew to the point where it was considered that even across the Atlantic, because of the increasing subjection of private enterprises to 'the fostering guardianship of the state', the 'laissez faire came to an end' (Landis 1938: 14, 8).

Even in a constitutional system like the American one which, in its classic eighteenthcentury form left no space for a 'fourth branch of Government,' 'the rise of administrative process' could now appear 'by all odds the most significant development in legal history in the last century' (Landis 1940: 1078).

The United States, therefore, joined the mainstream and saw, between the two World Wars, a sudden acceleration. With 'The Growth of Administrative Power', 'the difference between Anglo-American and French and Continental Law diminishes' (Freund 1923: 
15-16). However, significant differences remain between the American and the European path.

Above all, in the United States, 'the struggle for administrative legitimacy' (Kessler 2016: 718) was far from resolved by the outbreak of World War II. The great conflict between the New Deal coalition and the Supreme Court reflected, but in certain terms even surpassed, the political and economic struggles of the time (Ernst 2014). It was rooted in the eighteenth-century constitutional framework and the objective difficulty of the quest to normalize the administrative government within a consolidated balance of powers that seemed to exclude a truly administrative function. This classical liberal constitutional framework expressed a system of judicial review firmly entrusted to courts of general jurisdiction. It was based on property rights and economic rights, conceived by the seventeenth and eighteenth century Law of Nature, which in Europe were progressively losing ground to the affirmation of social rights and the principle of the indivisibility of rights. In spite of the significant progress in social security in the Roosevelt years, 'the United States remained a residual provider of welfare, preserving insurance-based benefits for particular groups deemed to be deserving and failed to develop major state service' (Oxford Handbook of the Welfare State 2010: 7).

The history of American administrative law can certainly be described as the 'occasional tilt' between 'progressive' and 'libertarian administrative law' (Sunstein and Vermeule 2015: 473), a frequently recurring theme. The opposing ideological forces found in the 1946 Administrative Procedure Act (APA) a decisive point of compromise and equilibrium. As the 'only general charter for judicial review of administrative action', (Vermeule 2009: 1107) the APA has remained the cornerstone of federal administrative law, even as its meaning has evolved over time through judicial interpretation and in reaction to changing constellations of political power and ideology. After the war, with Truman's Fair Deal, a solid reconciliation finally became possible between the culture of the lawyers, deeply rooted in common law and still loyal in its underlying principles to the version of Dicey's Rule of Law, and the new managerial culture of the administrators of the New Deal.

It is difficult, nevertheless, to think of anything similar on the European continent. What appeared to some as 'Tocqueville's Nightmare' in America (Ernst 2014) took on in Europe the appearance of a reassuring Etat providence, a welfare state, an Etat gestionnaire which was willing to take charge of an increasing number of social needs, widely accepted and increasingly present in the daily lives of European citizens. The common spirit of the time, for the whole Western universe, does not translate immediately into a set of institutions fully in tune with one another.

The question of legal guarantees for administrative actions on the continent was primarily an issue in the nineteenth century, undergoing a phase of only gradual adjustment between the two World Wars. There were few great changes, even in the German and Italian totalitarian system or in Vichy France. In the United States, on the contrary, judicial review was central to the American path in the first half of the twentieth century, due to contests over its scope of application and the content and intensity of the control over administrative action. Precisely because of this control function, doctrines of judicial review became the main instrument for refining a now consolidated administrative law. In Europe the issues of the administrative organization instead became absolutely central. Alongside authorities exercising the traditional puissance publique, and bodies carrying out the new tasks of service public, public corporations emerged, which were 
wielded by the offentliche Hand (public Hand) but performed exclusively commercial activities.

This is a further element of difference compared to the American path. The second industrial revolution in Europe was possible only due to direct state intervention in the economy. The state took action and intervened directly, as an economic player, in the market equilibrium. Even the services of economic interest were (or soon became) public services. The term 'public' should be interpreted not only in the sense that they must serve a general pool of users, as a universal service, but also because it refers to services performed by the state (or in any case by the public administration or by private enterprises under government concessions). Similar examples of public interventionism soon involved the banking and insurance sectors and even quite a few manufacturing sectors, especially in the field of heavy industry. The state that made inroads on the continent in the nineteenth and twentieth century was at the same time an Etat Providence and an entrepreneurial state.

\section{CONCLUSION}

The English and continental developments in administrative law reflect different starting points, paths and conceptions of legitimate governance that can be traced at least to the end of the eighteenth century.

Only at the beginning of the twentieth century does the vocabulary start to become uniform. The content instead, again during the period between the two World Wars, continues to reflect the varying constitutional and government architectures and national experiences. The equilibrium between public and private, in particular, is very different on the two sides of the Atlantic. In this sense, Dicey's famous 1915 definition was correct: 'a body of administrative law resembling in spirit, though certainly by no means identical with the administrative law (droit administratif) . . . of France' could no longer be denied in England $(1915,148)$ (emphasis added), or in the United States.

It is only over the last several decades that we have witnessed an increasing effort to definitely reconcile continental and common law traditions. Droit administratif has narrowed its radius of application, while also rediscovering judicial and procedural outlooks of a seemingly more Anglo-American character. In place of administration based on the idea of service public, one sees increased regulation and privatization. On the other hand, Anglo-American administrative law has increasingly distanced itself from its common law underpinnings, focusing instead on the prerogatives of general regulatory power in the face of social change. Globalization and the persistent economic crisis have further focused the attention of jurists on the still extremely fragmentary answers to global economic, political, and regulatory problems. Today, all administrative traditions face the same challenge: to offer global answers to problems of the public regulation of markets and society that now often transcend the borders of nation-states in which the particular traditions of administrative law developed. 


\section{REFERENCES}

Allison, John W.F. 1996. A Continental Distinction in the Common Law: A Historical and Comparative Perspective on English Public Law. Oxford: Oxford University Press.

Blackstone, William. 1884. Commentaries on the Laws of England (1 ${ }^{\text {st }}$ ed. 1765). Chicago: Callaghan.

Chaptal, Jean-Antoine. 1800. Corps législatif. Session du 28 pluviôse an VIII. Archives parlementaires, 2ème série, t.I, p. 230.

Craig, Paul. 2015. UK, EU and Global Administrative Law. Foundations and Challenges. Cambridge: Cambridge University Press.

Dicey, Albert Venn. 1915. The development of administrative law in England. Law Quarterly Review. 31: $148-53$.

Dicey, Albert Venn. 1959. Introduction to the Study of the Law of the Constitution. $10^{\text {th }}$ ed. London: Macmillan ( $1^{\text {st }}$ ed. 1885).

Domat, Jean. 1756. Le droit public, suite des Loix civiles dans leur ordre naturel. In Domat, Jean. Les Loix civiles dans leurs ordres naturel; le droit public et Legum delectus. Vol. 2. Paris: Cavelier.

Duguit, Léon. 1913. Les transformations du droit public. Paris: Colin.

Ernst, Daniel R. 2014. Tocqueville's Nightmare. The Administrative State Emerges in America, 1900-1940. Oxford: Oxford University Press.

Foucault, Michel. 1994. La gouvernementalité. In Foucault, Dits et ècrits 1954-1988, vol. 3, 1976-1979. Paris: Gallimard, 635-57.

Frankfurter, Felix. 1930. The Public and its Government. New Haven and London: Yale University Press.

Freund, Ernst. 1923. Historical Survey. In The Growth of American Administrative Law (E. Freund, R.V. Fletcher, J.E. Davies, C.W. Pound, J.A. Kurtz, C. Nagel). St. Louis: Thomas Law Book Company, 9-41.

Goodnow, Frank J. 1893. Comparative Administrative Law. An Analysis of the Administrative Systems National and Local of the United States, England, France and Germany. New York-London: G.P. Putnam's Sons.

Jellinek, Georg. 1914. Allgemeine Staatslehre. $3^{\text {rd }}$ ed. Berlin: Springer $\left(1^{\text {st }}\right.$ ed. 1900).

Kant, Immanuel. 1991. The Metaphysics of Morals. 1. The Doctrine of Right. Ed. by Mary Gregor. Cambridge: Cambridge University Press ( $1^{\text {st }}$ ed. 1797).

Kelsen, Hans. 1968a. Die Lehre von den drei Gewalten oder Funktionen des Staates (1 ${ }^{\text {st }}$ ed. 1923-24). In Die Wiener Rechtstheoretische Schule. Schriften von Hans Kelsen, Adolf Merkl, Alfred Verdross (edited by Hans Klecatsky, René Marcic, Herbert Schambeck), vol. 2. Wien: Europa, 1625-1660.

Kelsen, Hans. 1968b. Justiz und Verwaltung (1 ${ }^{\text {st }}$ ed. 1929). In Die Wiener Rechtstheoretische Schule. Schriften von Hans Kelsen, Adolf Merkl, Alfred Verdross (edited by Hans Klecatsky, René Marcic, Herbert Schambeck), vol. 2. Wien: Europa, 1459-83.

Kessler, Jeremy K. 2016. The struggle for administrative legitimacy (book review Tocqueville's Nightmare). Harvard Law Review. 129: 718-73.

Keynes, John Maynard. 1926. The End of Laissez Faire. London: Hogarth Press.

Landis, James. 1938. The Administrative Process. New Haven and London: Yale University Press.

Landis, James. 1940. Crucial issues in administrative law. The Walter-Logan Bill. Harvard Law Review. 53: 1077-102.

Laski, Harold J. 1925. A Grammar of Politics. London: Allen \& Unwin.

Lindseth, Peter. 2005. 'Always embedded' administration?: The historical evolution of administrative justice as an aspect of modern governance. In The Economy as a Polity: The Political Constitution of Contemporary Capitalism (edited by Christian Joerges, Bo Stråth and Peter Wagner). London: UCL Press.

Loughlin, Martin. 2009. Why the history of English administrative law is not written. In A Simple Common Lawyer. Essays in Honour of Michael Taggart (edited by David Dyzenhaus, Murray Hunt, Grant Huscroft). Oxford and Portland: Hart, 151-73.

MacDonagh, Oliver. 1958. The nineteenth-century revolution in government: a reappraisal. The Historical Journal. 1: 56-67.

Maitland, Friedrich William. 1908. The Constitutional History of England. Cambridge: Cambridge University Press.

Maitland, Friedrich William. 1987. Translator's Introduction. In Otto von Gierke, Political Theories of the Middle Age. Cambridge: Cambridge University Press (1 ${ }^{\text {st }}$ ed. 1900), VII-XLV.

Mannori, Luca and Sordi, Bernardo. 2001. Storia del diritto amministrativo. Rome-Bari: Laterza.

Mannori, Luca and Sordi, Bernardo. 2009. Administration and Administrative Law. In A Treatise of Legal Philosophy and General Jurisprudence, vol. 9, A History of the Philosophy of Law in The Civil Law World 1600-1900 (edited by Damiano Canale, Paolo Grossi, Hasso Hofmann). Dordrecht: Springer, 225-61.

Marx, Karl. 1973. The civil war in France. In K. Marx-F. Engels, Selected Works, Moscow, Progress, 178-243.

Mashaw, Jerry L. 2012. Creating the Administrative Constitution: The Lost One Hundred Years of American Administrative Law. New Haven and London: Yale University Press. 
Mayer, Otto. 1924. Deutsches Verwaltungsrecht. $3^{\text {rd }}$ ed. Berlin (Reprint Berlin 1961: Duncker \& Humblot) (1 $1^{\text {st }}$ ed. 1895).

Mestre, Jean-Louis. 1985. Introduction historique au droit administratif français, Paris PUF.

Montesquieu, Charles de Secondat et de. 1914. The Spirit of Laws. Transl. T. Nugent and J.V. Prichard. London: G. Bell \& Sons (electronic edition).

Oxford Handbook of the Welfare State. 2010 (edited by F.G. Castles, S. Leibfried, J. Lewis, H. Obinger, C. Pierson). Oxford: Oxford University Press.

Portalis, Jean-Etienne-Marie. 1999. Discours préliminaire du premier projet de Code civil. Paris: Confluences.

Robson, William. 1928. Justice and Administrative Law. A Study of the British Constitution. London: Macmillan. Senellart, Michel. 1995. Les arts de gouverner. Du regime médiéval au concept de gouvernement. Paris: Seuil.

Stolleis, Michael. 1982. Rechtsstaat. In Handwörterbuch zur deutschen Rechtsgeschichte (edited by Adalbert Erler and Ekkehard Kaufmann). Berlin: Schmidt, vol. 4, 367-75.

Stolleis, Michael. 1992. Geschichte des öffentlichen Rechts in Deutschland, vol. 2 1800-1914. Munich: Beck.

Sunstein Cass R. and Vermeule Adam. 2015 Libertarian administrative law. The University of Chicago Law Review. 82: 393-473.

Tocqueville, Alexis de. 1866. Rapport fait à l'Académie des Sciences Morales et Politiques (1846) sur le livre de M. Macarel, intitulé Cours de droit administratif. In Tocqueville, CEuvres Complètes. Vol. 9. Etudes économiques, politiques et littéraires. Ed. by Mary de Tocqueville and Gustave de Beaumont. Paris: Lévy, 60-75.

Tocqueville, Alexis de. 1969. L'Ancien Régime (edited by G.W. Headlam). Oxford: Clarendon Press.

Tocqueville, Alexis de. 1994. Democracy in America. (edited by J.P. Mayer, translated by George Lawrence). London: Fontana ( $1^{\text {st }}$ ed. $1835 ; 2^{\text {nd }}$ ed. 1840$)$.

Vermeule, Adam. 2009. Our Schmittian administrative law. Harvard Law Review. 122: 1095-149.

Wilson, Woodrow. 1887. The study of administration. Political Science Quarterly. 2: 197-222. 